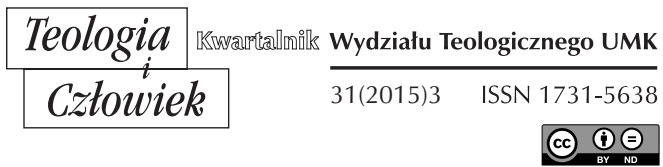

AGNIESZKA WYRĄBKIEWICZ*

TORUŃ

\title{
IDEAŁ MIŁOŚCI CHRZEŚCIJAŃSKIEJ. SYLWETKA ŚW. MAKRYNY MŁODSZEJ W PISMACH ŚW. GRZEGORZA Z NYSSY
}

DOI: http://dx.doi.org/10.12775/TiCz.2015.034

Spuścizna pierwszych wieków istnienia Kościoła zaskakuje obfitością literatury podkreślającej prymat stanu dziewiczego nad małżeństwem. Żywoty, listy, pisma apokryficzne, akta męczenników i traktaty hagiograficzne popularyzowały ideę bezżeństwa ${ }^{1}$, gloryfikując stan czystości seksualnej jako eschatologiczno-chiliastyczną postawę chrześcijan w opozycji do kultury świata pogańskiego, zawierającej w sobie silny element rozluźnienia więzów w dziedzinie seksualnej². Wczesnochrześcijańscy

* Doktorantka nauk teologicznych II roku na Uniwersytecie Mikołaja Kopernika. Ukończyła studia teologiczne w 2012 roku na Wydziale Teologicznym Uniwersytetu Mikołaja Kopernika. W roku 2011 otrzymała stypendium Ministra Nauki i Szkolnictwa Wyższego.

1 Wczesnochrześcijańskie pochwały wstrzemięźliwości seksualnej stanowiły zachętę do utrzymania stanu celibatu bądź wdowieństwa zarówno dla kobiet, jak i mężczyzn. Więcej na ten temat zob. J. Naumowicz, Wstęp, w: Pierwsze pisma greckie o dziewictwie, „Źródła monastyczne” 16, Kraków 1997, s. 16-45.

2 Por. M. Michalski, Problem dziewictwa i małżeństwa. Metody z Olimpu. Wstęp, w: tenże, Antologia literatury patrystycznej, Warszawa 1969, t. 1, z. 2, s. 296. 
myśliciele, poszukując najdoskonalszej drogi miłości, często akcentowali wyższość celibatu, jako wyjątkowego stanu oddania się Bogu, wiodącego przez praktyki ascetyczne do wyżyn świętości na wzór bytów anielskich wolnych istot bezcielesnych, całkowicie oddzielonych od wszelkich form namiętności. Z takim właśnie obrazem świętości spotykamy się w De virginitate, traktacie ascetycznym otwierającym pisarską działalność św. Grzegorza z Nyssy, a także paralelnym tematycznie, choć nieco późniejszym, Vita sanctae Macrinae. Główne linie teologiczne obu pism ogniskują się wokół sylwetki siostry Kapadockiego autora - Makryny Młodszej, która własną naturę doprowadziła do tak wielkiego wyniesienia, dzięki czemu już w doczesności cieszyła się posiadaniem najdoskonalszego stopnia miłości.

Chcąc przyjrzeć się bliżej owemu anielskiemu niemal ideałowi miłości zobrazowanemu w postaci Makryny, warto zwrócić uwagę na znamienny rys całego dorobku Autora biografii świętej, który dotyczy specyfiki i bogactwa terminologii miłości, przenikającej wszystkie rodzaje jego pism, w tym wspomnianych już De virginitate i Vita sanctae Macrinae. Grzegorz obficie korzysta w nich z języka przyjętego w No-

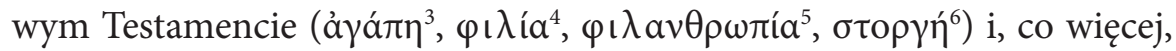
podobnie jak Orygenes i Metody z Olimpu, sięga po - wzbudzający niemałe kontrowersje wśród chrześcijan - pogański termin épwৎ oraz jego pochodne $e^{7}$. Bogactwo semantyczne wskazanych słów, w tym pejoratywne dla wierzącego skojarzenia, nie zahamowały Nysseńczyka przed użyciem tak osobliwego słownictwa nawet wobec opisu stanu dziewiczego. Dlatego też krótka charakterystyka dzieł poświęconych Makrynie, jak i odczytanie motywu łączenia w Żywocie - tak wyjątkowej dla Biografa świętej - różnorodnych oblicz miłości stanowić będzie cel niniejszego artykułu.

3 Por. Lexicon Gregorianum: Wörterbuch zu den Schriften Gregors von Nyssa, red. F. Mann, Leiden-Boston-Köln 1999, t. 1, s. 32-34.

${ }^{4}$ Por. tamże, Leiden-Boston 2013, t. 9, s. 464-465.

${ }^{5}$ Por. tamże, s. 457-460.

${ }^{6}$ Por. tamże, Leiden-Boston 2010, t. 8, s. 204.

7 Por. tamże, Leiden-Boston 2001, t. 3, s. 521-522. 


\section{MAKRYNA W PIŚMIENNICTWIE WCZESNOCHRZEŚCIJAŃSKIM}

W ostatnim dziesięcioleciu zauważalny jest znaczący wzrost zainteresowania postacią Makryny Młodszej wśród historyków, patrologów i filologów klasycznych zarówno w literaturze międzynarodowej ${ }^{8}$, jak i polskojęzycznej9, głównie dzięki ważnej roli w rozwoju ascetycznej

${ }^{8}$ E. Bouvy, Sainte Macrine, „Revue agustinienne” 1902, nr 1, s. 265-288; F. J. Dölger, Das Anhängekreuzchen der hl. Macrinaundihr Ring mit der Kreuzpartikel. Ein Beitrag zur religiösenVolkskunde des IV Jahrhunderts nach der Vita Macrinae des Gregor von Nyssa, „Antike und Christentum” 1932, nr 3, s. 81-116; J. E. Pfister, A Biographical Note. The Brothers and Sisters of Gregory of Nyssa, „Vigiliae Christianae” 1964, nr 18, s. 108-113; P. Maraval, Encore lesfrères et sœurs de Grégoire de Nysse, „Revued'Histoire et de Philosophie Religieuses" 1980, nr 60, s. 161-166; R. Albrecht, Das Leben der heiligen Makrina auf dem Hintergrund der Thekla-Traditionen. Studienzu den Ursprüngen des weiblichen Mönchtums im 4. Jahrhundert in Kleinasien, Göttingen 1986; E. Giannarelli, Macrina e sua Madre: Santità e Paradosso, „Studia Patristica” 1989, nr 20, s. 224-230; G. Frank, Macrina's Scar. Homeric Allusion and Heroic Identity in Gregory of Nyssa's Life of Macrina, "Journal of Early Christian Studies” 2000, nr 8, s. 511-530; F. Cardman, Whose Life Is It? The Vita Macrinae of Gregory of Nyssa, „Studia Patristica” 2001, nr 37, s. 33-50; J. Warren Smith, A Just and Reasonable Grief. The Death and Function of a Holy Woman in Gregory of Nyssa's Life of Macrina, "Journal of Early Christian Studies” 2004, nr 12, s. 57-84; A. M. Silvas, Anna Macrina the Younger, Philosopher of God, Turnhout 2008; J. W. Smith, Macrina, Tamer of Horses and Healer of Souls. Grief and the Therapy of Hope in Gregory of Nyssa's De Anima et Resurrectione, "The Journal of Theological Studies” 2001, nr 52, s. 37-60; L. F. Mateo-Seco, Macrina, w: The Brill Dictionary of Gregory of Nyssa, eds. L. F. Mateo-Seco, G. Maspero, tran. S. Cherney, „Vigiliae Christianae” Supplements 99, Leiden-Boston 2010, s. 471-474; E. Muehlberger, Salvage: Macrina and the Christian Project of Cultural Reclamation, „Church History: Studies in Christianity and Culture" 2012, nr 81, s. 273-297; A. P. Urbano, The Philosophical Life. Biography and the Crafting of Intellectual Identity in Late Antiquity, „North Monograph Series” 21, Washington 2013 - zwłaszcza rozdział: Macrina and Sosipatra: Beyond Their Nature, s. 245-272; L. Karfíková, Gregory of Nyssa, Witness of Macrina's Life and Death, „Theologica Olomucensia” 2013, nr 14, s. 15-26.

9 Por. S. Strękowski, Makryna Młodsza - mistrzyni życia duchowego według św. Grzegorza z Nyssy, w: Kobieta w starożytności chrześcijańskiej. Materiały Sympozjum Patrystycznego, 22.10.1998 ATK, „Studia Antiquitatis Christianae” 14, Warszawa 1999, s. 43-52; R. Wiśniewski, Makryna albo o poszukiwaniu modelu taumaturgii kobiecej, w: Chrześcijaństwo u schyłku starożytności. Studia źródłoznawcze, red. T. Derda, E. Wipszycka, t. 3, Kraków 2000, 309-311; J. Dybała, Ideał kobiety w pismach kapadockich Ojców Kościoła i Jana Chryzostoma, Łódź 2012 [oraz wydany w formie artykułu wycinek 
społeczności kobiet ${ }^{10}$. Fakt ten może jednak budzić zdziwienie biorąc pod uwagę, jak nielicznymi przekazami na temat świętej dysponujemy do dziś. W zasadzie najważniejsze świadectwa patrystyczne skupiają się wokół trzech pism Grzegorza z Nyssy, w których Makryna zostaje bezpośrednio wspominana. Chronologicznie pierwszą wzmiankę na temat siostry Biskupa znajdujemy w Liście do niejakiego Jana (tzw. Epistulae 1911), zawierającym krótką informację o jej życiu ${ }^{12}$. W kolejnym dziele - Vita sanctae Macrinae, datowanym przez większość badaczy na rok $381^{13}$, znajdują się niemal kompletne wiadomości o życiu Makryny, choć sam Autor nie podkreśla obiektywności w tworzeniu osobistego wspomnienia ${ }^{14}$ o świętej, zmarłej w lipcu $379^{15}$. Dopełnieniem sylwetki jest Dialogus de anima et resurrectione, który relacjonuje rozmowę Grzegorza i Makryny toczącą się w 379 roku, wkrótce po śmierci ich brata Bazylego, gdy Nysseńczyk, wracając z synodu w Antiochii, odwiedził kona-

z rozprawy doktorskiej: Makryna Młodsza, czyli kto? Postać świętej w pismach Grzegorza z Nyssy, „Przegląd Nauk Historycznych” 2011, nr 10, z. 2, s. 27-51, stanowiący rozdział powyższej książki].

${ }^{10}$ Por. J. Quasten, Patrology, vol. 3: The Golden Age of Greek patristicliterature from the Council of Nicaea to the Council of Chalcedon, Utrecht 1960, s. 261.

${ }^{11}$ Gregorius Nyssenus, Epistula 19, ed. J. P. Migne, Patrologiae cursus completus. Series Graeca 46, Paris 1863, 1071B-1080A.

${ }^{12}$ Wszystkie listy Grzegorza pochodzą z okresu biskupiego (po konsekracji w 371 roku), prawdopodobnie pisane były w krótkim okresie, ponieważ za ich dolną datę graniczną uznaje się rok śmierci Bazylego Wielkiego (379). Zob. P. Maraval, Chronology of works, w: The Brill Dictionary of Gregory of Nyssa, eds. L. F. Mateo-Seco, G. Maspero, tran. S. Cherney, „Vigiliae Christianae” Supplements 99, Leiden-Boston 2010, s. 160.

${ }^{13}$ Por. J. Daniélou, La Chronologie des sermons de Grégoire de Nysse, „Recherches de Science Religeuses" 29 (1955), s. 359; J. Naumowicz, dz. cyt., s. 32; L. F. Mateo-Seco, De virginitate, w: The Brill Dictionary of Gregory of Nyssa, eds. L. F. Mateo-Seco, G. Maspero, tran. S. Cherney, „Vigiliae Christianae” Supplements 99, Leiden-Boston 2010, s. 774-776; J. Dybała, Ideał kobiety, s. 74. Niektórzy badacze datują powstanie Żywotu między ostatnimi miesiącami 381 roku a przełomem 382/382. Zob. P. Maraval, Chronology of works, s. 160.

${ }^{14}$ Por. L. Karfíková, Gregory of Nyssa, Witness of Macrina's Life and Death, „Theologica Olomucensia” 2013, nr 14, s. 15.

${ }_{15}$ Por. L. F. Mateo-Seco, Macrina, w: The Brill Dictionary of Gregory of Nyssa, eds. L. F. Mateo-Seco, G. Maspero, tran. S. Cherney, „Vigiliae Christianae” Supplements 99, Leiden-Boston 2010, s. 473; P. Maraval, Chronology of works, s. 156. 
jącą siostrę ${ }^{16}$. Niemniej badacze Dialogu nie są zgodni co do daty jego powstania ${ }^{17}$.

Oprócz przekazów Biskupa Nyssy Makryna została również wspominana w Epitafia $120^{18}$ św. Grzegorza z Nazjanzu. Zwięzły epigram podkreśla szlachetność Dziewicy, najstarszej i wielkiej córki Emmelii, której chwała wznosi się ponad cały lud. Ciekawym pozostaje jednak fakt, że postać świętej nie została przywołana w obfitej spuściźnie -najstarszego z braci Makryny - Bazylego Wielkiego ${ }^{19}$.

\section{a. De virginitate}

Oprócz wymienionych powyżej dzieł św. Grzegorza z Nyssy należy przywołać jeszcze jeden znamienny traktat, korespondujący tematycznie z Vitae sanctae Macrina, powstały niemalże 10 lat przed spisaniem Żywotu, a więc otwierający działalność pisarską Autora De virginitate ${ }^{20}$. Omawiana rozprawa ascetyczna napisana została na polecenie Bazylego Wielkiego, wkrótce po jego wyborze na biskupa w 370 roku, jeszcze przed otrzymaniem przez Grzegorza sakry biskupiej w 371 roku $^{21}$. Pierwsze

16 Por. J. Quasten, Patrology, s. 261.

17 Por. J. Daniélou (La Chronologie, s. 356) wykazuje, że Dialog powstał podczas zimy 380/381, zaś niektórzy naukowcy przedłużają okres powstania traktatu nawet na okres pomiędzy 381 a 383 rokiem. Zob. P. Maraval, Chronology of works, s. 156.

${ }^{18}$ Epitafia 120, ed. J. P. Migne, Patrologiae cursus completus. Series Graeca 38, Paris $1862,75-76$.

19 Por. J. Dybała, Ideał kobiety, s. 291.

${ }^{20}$ Wydania krytyczne: Grégoire de Nysse, Traté de la virginité, ed. M. Aubienau, „Sources Chrétiennes” 119, Paris 1966; ed. J. P. Migne, Patrologiae cursus completus. Series Graeca 46, Paris 1863, 317-416; ed. J. P. Cavarnos, Gregorii Nysseni Opera 8/1, Leiden 1952, s. 215-343; Tłumaczenia: M. Aubineau, Grégoire de Nysse, Traité de la virginité, „Sources Chrétiennes” 119, Paris 1966; V. Woods Callahan, Gregory of Nyssa, On Virginity, w: Gregory of Nyssa, Ascetical Works. The Fathers of the Church, Washington 1967, v. 58, s. 3-75; W. Blum, Gregor von Nyssa, Überdas Wesen des christlichen Bekenntnisses, Über die Vollkommenheit, Über die Jungfräulichkeit, Stuttgart 1977, s. 81-153; S. Lilla, Gregorio di Nissa, La Virginità, Rome 1990; L. F. Mateo-Seco, Grégoire de Nysse, La virginidad, Madrid 2000.

${ }^{21}$ Wydania krytyczne: Grégoire de Nysse, Traté de la virginité, ed. M. Aubienau, „Sources Chrétiennes” 119, Paris 1966; ed. J. P. Migne, Patrologiae cursus completus. Series Graeca 46, Paris 1863, 317-416; ed. J. P. Cavarnos, Gregorii Nysseni Opera 8/1, Leiden 1952, s. 215-343; Tłumaczenia: M. Aubineau, Grégoire de Nysse, Traité de la virginité, 
dzieło Nysseńczyka zawiera liczne paralele do treści zawartych w - najlepiej zachowanym traktacie św. Metodego z Olimpu - Symposion ton deka parthenon ${ }^{22}$ i zdradza najbardziej charakterystyczne elementy rozwiniętych w późniejszym dorobku koncepcji teologiczno-filozoficznych Kapadocczyka, m.in. realistyczną jedność natury ludzkiej, idee cnót pojętych jako właściwe katalizatory procesu przebóstwienia, naśladownictwo Bożej natury przez apatheię oraz nieustanny progres uczestnictwa w Bogu zaprezentowanym najpełniej $\mathrm{w}$ doktrynie epektazy.

Pismo to Grzegorz skierował do mnichów i bezżennych kobiet ${ }^{23}$, pragnących przyozdobić się świętą oraz, nieposiadającą skazy, łaską dziewictwa $^{24}$, co też stanowiło główny cel wychowania, ku któremu Makryna prowadziła powierzoną sobie żeńską, quasi-monastyczną wspólnotę nad rzeką Irys w Poncie. Jak twierdzi ks. Prof. Józef Naumowicz, traktaty De virginitate oraz Vita sanctae Macrinae tworzą integralną całość, ukazując ścisły związek między teorią i praktyką dziewictwa ${ }^{25}$. Dlatego też sylwetka

„Sources Chrétiennes” 119, Paris 1966; V. Woods Callahan, Gregory of Nyssa, On Virginity, w: Gregory of Nyssa, Ascetical Works. The Fathers of the Church, Washington 1967, v. 58, s. 3-75; W. Blum, Gregor von Nyssa, Überdas Wesen des christlichen Bekenntnisses, Über die Vollkommenheit, Über die Jungfräulichkeit, Stuttgart 1977, s. 81-153; S. Lilla, Gregorio di Nissa, La Virginità, Rome 1990; L. F. Mateo-Seco, Grégoire de Nysse, La virginidad, Madrid 2000.

${ }^{22}$ Methodiu, Symposion ton deka parthenon, ed. J. P. Migne, Patrologiae cursus completus. Series Graeca 18, Paris 1857, s. 27-217. Tłumaczenie polskojęzyczne: Metody z Olimpu, Uczta, tłum. S. Kalinkowski, w: Pierwsze pisma greckie o dziewictwie, „Źródła Monastyczne” 16, Kraków 1997, s. 127-253. Grzegorz utworzył zasadnicze zręby doktryny o jedności natury ludzkiej inspirując się intuicją Metodego z Olimpu, z którym dzieli wspólne stanowisko wobec wczesnochrześcijańskiej kontrowersji posługiwania się językiem erosa do opisów miłosnej relacji między człowiekiem a Bogiem. Por. A. Nygren, Agape und Eros. Gestaltwandlungen der christlichen Liebe, Berlin 1955, s. 318-342. Więcej na temat napięcia wokół terminologii miłosnej w pismach Metodego zob. E. Prinzivalli, Desiderio di generazione e generazione del desiderio. Metodio di Olimpio e le polemiche sulleros fra III e IV secolo, w: L'eros difficile. Amore e sessualitànell'anticocristianesimo, red. S. Pricoco, Soveria Mannelli 1998.

${ }^{23}$ Por. J. Naumowicz, dz. cyt., s. 32.

${ }^{24}$ Por. Gregorius Nyssenus, De virginitate 1, ed. J. P. Migne, Patrologiae cursus completus. Series Graeca 46, Paris 1863, 320D.

${ }_{25}$ Por. J. Naumowicz, dz. cyt., s. 32; L. F. Mateo-Seco, De virginitate, s. 774-776; J. Dybała, Ideał kobiety, s. 74. 
Makryny opisana w Żywocie stanowi wcielenie koncepcji znajdujących się w De virginitate, co znajduje szczególne uzasadnienie w rozdziale 23 traktatu, w którym Nysseńczyk wywyższa przykłady świętych nad spisanymi regułami ${ }^{26}$.

\section{b. Vita sanctaeMacrinae}

Żywot św. Makryny to najstarsza zachowana wielka biografia chrześcijańska kobiety dziewicy, napisana w formie listu ${ }^{27}$. Powstała najprawdopodobniej po powrocie Grzegorza z Jerozolimy, zimą 381-382 roku ${ }^{28}$, Vita sanctae Macrinae ${ }^{29}$ może być uważana za manifest żeńskiego monastycyzmu, ponieważ przynosi cenne informacje o najbardziej rudymentalnej formie zakonów żeńskich, sięgając samych początków - gdy nie ma jeszcze reguły, ślubów, określonych ram organizacyjnych, ale jest gorące umiłowanie ideału dziewictwa poświęconego Bogu i autentycznej miłości Boga spalającej się na rzecz służby bliźnim ${ }^{30}$. Opisuje on dzieje życia Makryny,

${ }^{26}$ Por. Gregorius Nyssenus, De virginitate 23, PG 46, 405B-410B.

27 Por. G. Frank, Macrina's Scar. Homeric Allusion and Heroic Identity in Gregory of Nyssa's Life of Macrina, „Journal of Early Christian Studies” 2000, nr 8, s. 511-530; L. F. Mateo-Seco, MACR. Vita Macrinae, w: The Brill Dictionary of Gregory of Nyssa, eds. L. F. Mateo-Seco, G. Maspero, tran. S. Cherney, „Vigiliae Christianae” Supplements 99, Leiden-Boston 2010, s. 469; L. Karfíková, Gregory of Nyssa, s. 16.

${ }_{28}$ Por. J. Daniélou, La Chronologie, s. 359; P. Maraval, Chronology of works, s. 160.

29 Wydania krytyczne: ed. J. P. Migne, Patrologiae cursus completus. Series Graeca 46, Paris 1863, 959-1000; ed. V.W. Callahan, Gregorii Nysseni Opera 8/1, Leiden 1952, s. 370-414. Tłumaczenia: M. Bednarz, Św. Grzegorz z Nyssy, Modlitwa na łożu śmierci, w: A. Bober, Światła ekumeny. Antologia patrystyczna, Kraków 1965, s. 134-136; P. Maraval, Grégoire de Nysse, Vie de sainte Macrine, „Sources Chrétiennes” 178, Paris 1971, s. 136-266; W. Kania, Św. Grzegorz z Nyssy, Życie św. Makryny, „AnalectaCracoviesia” 1971, nr 3, s. 387-404; K. Corrigan, The Life of Saint Macrina by Gregory, Bishop of Nyssa, Saskatoon 1987; E. Giannarelli, Gregorio di Nissa, Vita di santa Macrina, Cinisello Balsamo 1988; E. Marotta, Gregorio di Nissa, Vita di santa Macrina, Rome 1989; F. Quéré, Mariage et virginité dans l'Eglise ancienne, Paris 1990, s. 66-100; C. Moreschini, Opere di Gregorio di Nissa, Turin 1992, s. 345-385; L. F. Mateo-Seco, Grégoire de Nysse, Vida de Macrina. Elogio de Basilio, Madrid 1995, s. 15-116; V. Woods Callahan, Gregory of Nyssa, On the Soul and the Resurrection, w: Gregory of Nyssa, Ascetical Works. The Fathers of the Church, Washington 2010, v. 58, s. 195-272.

${ }^{30}$ Por. A. Bober, Św. Grzegorz z Nyssy. Życie św. Makryny. Przedmowa, „Analecta Cracoviesia" 1971, nr 3, s. 384. 
a także zawiera obszerną relację ze spotkania z nią w kilka dni przed śmiercią oraz szczegółowym opisem jej pogrzebu.

Grzegorz zaznacza cel napisania Żywotu w słowach: „W przekonaniu, że opis życia szlachetnego człowieka przyniesie pożytek - by nie pozostał on ukryty przed przyszłością i ta, która życiową mądrością doszła do najwyższych granic ludzkiej cnoty zasłonięta milczeniem nie minęła bez pożytku dla drugich - idę za twą radą, i, ile to możliwe, przedstawię krótko jej życie"31. Makryna zostaje więc zaprezentowana jako doskonały wzór do naśladowania, co sprawia, że biografia otrzymuje charakter utylitarny i parenetyczny, a także staje się modlitwą dziękczynną Nysseńczyka za dar tak wspaniałej siostry ${ }^{32}$. Jak zostało już wspomniane powyżej, dla Grzegorza Vitae sanctae Macrinae stanowi osobiste świadectwo o wyjątkowej świętej3, czym zestawia ją z pochwałami cnotliwego życia, jakie zawarł w późniejszym traktacie egzegetycznym De vita Mosis oraz biografii De vita Gregorii Thaumaturgi. Tym samym Grzegorz nie podjął się napisania własnej autobiografii, jak to uczynili m.in. Augustyn czy Grzegorz z Nazjanzu ${ }^{34}$.

\section{c. Dialogus de anima et resurrectione}

Dialogus de anima et resurrectione $e^{35}$, opisujący ostatnią rozmowę Grzegorza z siostrą Makryną, jest chrześcijańskim odpowiednikiem Pla-

${ }^{31}$ Gregorius Nyssenus, Vita sanctae Macrinae, ed. J. P. Migne, Patrologiae cursus completus. Series Graeca 46, Paris 1863, 960BC; tłum. W. Kania, w: Grzegorz z Nyssy, Życie św. Makryny „Analecta Cracoviesia” 1971, nr 3, s. 387.

32 Por. J. Dybała, Ideał kobiety, s. 292.

${ }^{33}$ Por. Gregorius Nyssenus, Vita sanctae Macrinae, PG 46, 960BC.

34 Por. L. Karfíková, Gregory of Nyssa, s. 15.

${ }^{35}$ Wydanie krytyczne: ed. J. P. Migne, Patrologiae cursus completus. Series Graeca 46, Paris 1863, s. 12-160. Tłumaczenia: T. Sinko, Grzegorz z Nyssy, Z dialogu „O duszy i zmartwychwstaniu”, w: Grzegorz z Nyssy, Wybór pism, Warszawa 1963, s. 137-153; V. Woods Callahan, Gregory of Nyssa, On the Soul and the Resurrection, w: Gregory of Nyssa, Ascetical Works, The Fathers of the Church, Washington 1967, v. 58, s. 195-272; W. Kania, Grzegorz z Nyssy, Dialog z siostra Makryna o Duszy I zmartwychwstaniu, w: Grzegorz z Nyssy, Wybór pism, Warszawa 1974, s. 27-87; C. Moreschini, Opere di Gregorio di Nissa, Torino 1992, s. 389-486; C. P. Roth, Gregory of Nyssa, The Soul and the Resurrection, Crestwood 1993; J. Tirrieux, Grégoire de Nysse, Sur lâme et la résurrection, Paris 1995; Ch. Bouchet, Grégoire de Nysse, L’âme et la résurrection, Paris 1998; I. Ramelli, Gregorio di Nissa, Sullanima e la resurrezione, Bompiani-Milano 2007. 
tońskiego Fedona. Spotkanie rodzeństwa odbyło się w 379 roku, wkrótce po śmierci ich brata Bazylego. Wówczas Grzegorz, wracając z synodu w Antiochii, odwiedził swoją siostrę, obejmującą w tym czasie urząd przełożonej klasztoru nad rzeką Iris w Poncie, gdzie znalazł ją konającą ${ }^{36}$. Wąskie ramy objętościowe Vita sanctae Macrinae nie pozwoliły na przytoczenie nauk głoszonych przez Makrynę pod wpływem Ducha Świętego, dlatego ich treść poznajemy w Dialogu ${ }^{37}$, dzięki czemu zyskuje on bardziej spekulatywny charakter.

Dostępne źródła nie pozwalają ustalić jaki poziom wykształcenia otrzymała Makryna. W Żywocie wychowywanie świętej ogranicza się tylko do codziennej recytacji Psalmów i pobożnej lektury Pisma Świętego ${ }^{38}$, zaś Dialogi ujawniają, że była ona zapoznana także z poglądami stoików i epikurejczyków ${ }^{39}$. Pouczenia dotyczące duszy, śmierci, zmartwychwstania oraz ostatecznego przywrócenia wszystkich rzeczy do stanu sprzed upadku (apokatastaza), które Biskup Nyssy wkłada w jej usta, są jego własnymi poglądami na temat orygenizmu. Jako biograf, Kapadocczyk uznał, że należy uwypuklić zdolności intelektualne Makryny, która była dla niego przede wszystkim ucieleśnieniem ideału chrześcijańskiego filozofa, stąd przybrany dyskurs stawiający świętą $\mathrm{w}$ roli nauczycielki ${ }^{40}$.

\section{1l. "OBLICZA MIŁOŚCl" MAKRYNY W VITA SANCTAE MACRINAE I DE ANIME ET RESURRECTIONEM}

Pisma bezpośrednio poświęcone Makrynie oraz te, z którymi zachodzi niewątpliwa korelacja treściowa (o czym wspomnieliśmy powyżej) obfitują nie tylko w główne wątki doktrynalne myśli Nysseńczyka, lecz zawierają przemyślaną koncepcję miłości chrześcijańskiej, ukazaną w sposób syntetyczny w ideale życia dziewiczego. Różnorodność oblicz miłości,

36 Por. J. Quasten, Patrology, s. 261.

37 Por. J. Dybała, Ideał kobiety, s. 307.

38 Por. Gregorius Nyssenus, Vita sanctae Macrinae, PG 46, 961D-964A.

39 Por. Gregorius Nyssenus, Dialogus de anima et resurrectione, ed. J. P. Migne, Patrologiae cursus completus. Series Graeca 46, Paris 1863, $21 \mathrm{~B}$.

${ }^{40}$ Por. J. Quasten, Patrology, s. 261; J. Dybała, Ideat kobiety, s. 308-309; L. Karfíková, Gregory of Nyssa, s. 18. 
które we wspomnieniach Grzegorza zdobią jego świętą siostrę, wiążą się $\mathrm{z}$ bardzo świadomie i precyzyjnie stosowaną terminologią. Wszystkie te oblicza, choć na pierwszy rzut oka wydawać się mogą niekiedy sprzeczne, w gruncie stanowią swoisty synergizm miłości, synergizm łączący ả $\gamma a ́ \pi \eta$,

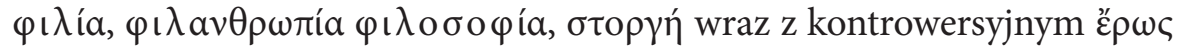
w jeden pełny, komplementarny i nierozdzielny ideał miłości wierzącego.

\section{a. $\dot{\alpha} \gamma \alpha \dot{\pi} \pi \eta$}

Częstotliwość występowania terminu agape i jego pochodnych we wszystkich pismach Nysseńczyka nie jest zaskakująca. Grzegorz setki razy używa rzeczowników, przymiotników i czasowników tej grupy, by wyrazić zarówno miłość Boga do człowieka, jak i odpowiedź człowieka względem Boga, miłość międzyludzką czy samą naturę Boga zgodnie z $1 \mathrm{~J} \mathrm{4,8.} 16$. W tym sensie agape jest terminem bardzo ogólnym ${ }^{41}$ i pierwszorzędnym, ponieważ stanowi fundament łaski dla duszy ${ }^{42}$. Termin ten odgrywa też zasadniczą rolę w prezentacji sylwetki Makryny, która, według wspomnień brata obecnego podczas jej śmierci, wyznaje w godzinie agonii: „Boże wieczny! Od łona matki należę do Ciebie, którego serce moje ze wszystkich sił umiłowało. Tobie poświęciłam od dziecka swoje ciało i serce"43. Jednak prawdziwa głębia agapetologii Grzegorza zostaje wypowiedziana przez Świętą w Dialogus de anima et ressurectione: Gdy dusza po usunięciu wszystkich naturalnych uczuć osiągnęła podobieństwo do Boga i, pozostawiając za sobą pożądanie, poszła tam, gdzie ją ono zaprowadziło, nie ma już miejsca dla nadziei i pamięci. To bowiem, czego się spodziewała, już posiada i zatopiona w zażywaniu wszelkiego dobra usuwa z myśli pamięć. Tak według szczególnych właściwości natury Boskiej ukształtowana, żyje wyższym, Boskim życiem, i nie ma już innych uczuć, jak tylko miłość, związana nierozerwalnie z dobrem. Miłość bowiem jest wewnętrzną skłonnością ku temu, co się podoba ${ }^{44}$.

${ }^{41}$ Por. G. Maspero, Love. åxá $\pi \eta$, ع́ $\rho \omega \varsigma$, w: The Brill Dictionary of Gregory of Nyssa,eds. L. F. Mateo-Seco, G. Maspero, tran. S. Cherney, „Vigiliae Christianae” Supplements 99, Leiden-Boston 2010, s. 457.

${ }^{42}$ Por. Gregorius Nyssenus, De instituto Christiano, w: tenże, Opera ascetica, ed. W. Jaeger, Gregorii Nysseni Opera 8/1, Leiden 1963, s. 61.

${ }^{43}$ Gregorius Nyssenus, Vita sanctae Macrinae, PG 46, 984D; tłum. W. Kania, w: Grzegorz z Nyssy, Życie św. Makryny, „Analecta Cracoviensia” 1971, nr 3, s. 397.

${ }^{44}$ Gregorius Nyssenus, Dialogus de anima et resurrectione, PG 46, 93C; tłum. W. Kania, w: Grzegorz z Nyssy, Wybór pism, Warszawa 1974, s. 60. 
Powyższy fragment stanowi Grzegorzową definicję agape ujętą jako

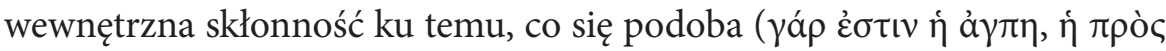

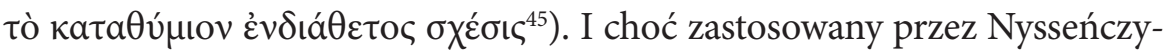
ka definiens ma naturę ogólną, zostaje uszczegółowiony w poprzedzającym go opisie, który wiąże agape $\mathrm{z}$ odwzorowaniem istoty Boskiej natury. Agape jest więc skłonnością ku temu, co się podoba, zaś najwyższym dobrem pożądanym przez człowieka jest życie według właściwości natury Boga. Odniesienie do wymiaru trynitarnego jest tu kluczowe i jawi się jako adekwatny miernik miłości ludzkiej. Co więcej, jest to zaproszenie do kształtowania własnej egzystencji na wzór miłości, będącej życiem najwyższej natury ${ }^{46}$. Człowiek, który przez stwórczy akt wychodzi z łona Miłości-Agape ${ }^{47}$, zostaje wezwany do wchodzenia w immamentne życie i relacje miłości charakterystyczne dla Osób Trójcy ${ }^{48}$. W tym kontekście właściwej wagi nabierają przytoczone już słowa Makryny, która od najmłodszych lat z całej duszy i ze wszystkich sił umiłowała Boga tą doskonałą miłością

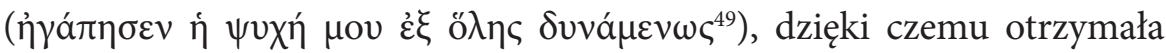
możliwość uczestnictwa w immamentnym życiu Boga. Problem ogniskuje się również w połączeniu przez Grzegorza tak pojętej agape z dziewictwem wzorowanym na czystych relacjach wewnątrztrynitarnych, które stanowią znak powrotu do bycia stworzonym „na obraz i podobieństwo

45 Por. tamże.

${ }^{46}$ Por. tamże, PG 46, 96C.

47 Por. Gregorius Nyssenus, In inscriptiones Psalmorum, ed. J. Donough, Gregorii Nysseni Opera 5, Leiden 1962, s. 162; tłum. M. Przyszychowska, w: Grzegorz z Nyssy, O tytułach psalmów, „Źródła Myśli Teologicznej” 72, Kraków 2014, s. 115: „Zrozumiesz te słowa, jeśli zbadasz, czym było pierwsze łono ludzkiej natury, czym brzuch, który nosił w sobie ludzkość. Sądzę, że jest nim miłość i dobroć Boga, dzięki której powstaliśmy i zostaliśmy ukształtowani. Ten bowiem, który sam stworzył ludzkie serca, powiedział: Stwórzmy człowieka na nasz obraz i podobieństwo. A następnie mówi: Zrodziłem i wywyższyłem synów, lecz wzgardzili Mną. Mnóstwo jest takich tekstów w Piśmie Świętym, z których można wywnioskować, czym było łono, które nas zrodziło i wydało na świat". Grzegorz nie używa w wyrażeniu miłość i dobroć Boga terminu agape, lecz filantropia, ponieważ na określenie natury Boga, stosuje wskazane terminy zamiennie. Nigdy jednak natury Boga nie opisuje terminem eros.

${ }^{48}$ Por. G. Maspero, dz. cyt., s. 459.

49 Por. Gregorius Nyssenus, Vita sanctae Macrinae, PG 46, 984D. 
Boga" ${ }^{\text {50 }}$, co też stanowi echo nauk św. Metodego z Olimpu określającego Chrystusa jako Arcydziewicę ${ }^{51}$. Dziewictwo jest więc dla Grzegorza pierwotnym stanem człowieka, praktyczną zapowiedzią połączenia protologii z eschatologią oraz stanem czystości serca, wyzwolenia się z wad, kontrolą namiętności i uczuć, charakteryzujących boską apatheię̨ ${ }^{52}$. Dlatego też sylwetka Makryny, która - zgodnie z całokształtem jej kreacji w Vita sanctae Macrine oraz fragmencie Epistula $19^{53}$ - dzięki intensywnej pracy nad własną naturą została wyniesiona do stanu anielskiej beznamiętności. Według Grzegorza ziszcza w sobie tak wzniosły ideał agape i dostępuje chwały samego Chrystusa wedle słów De virginitate: „To, co się fizycznie ziściło w Maryi Niepokalanej, gdy pełnia bóstwa zajaśniała w Chrystusie poprzez dziewictwo, powtarza się także w każdej duszy, która, idąc za rozumem, pozostaje dziewicą, chociaż Pan nie uobecnia się już mate-

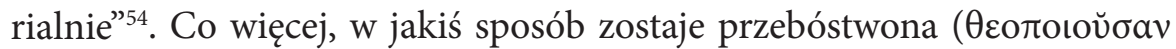

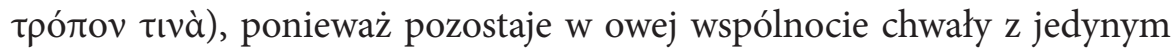
prawdziwie świętym i nieskalanym Bogiem ${ }^{55}$.

b. عُ $\rho \omega \varsigma$

W monumentalnej pracy szwedzkiego teologa - Andersa Nygrena, Agape und Eros. Gestaltwandlungen der christlichen Liebe znajdujemy krytykę deformacji ewangelicznego pojęcia miłości poprzez poddanie się ojców Kościoła, a zwłaszcza Nysseńczyka, pokusie hellenizacji, która biblijne agape zastąpiła obciążonym negatywnymi konotacjami terminem eros $(\varepsilon \tilde{\rho} \rho \varsigma)^{56}$. I choć w pismach Grzegorza istnieje zasadnicza różnica $\mathrm{w}$ częstotliwości występowania obu terminów, ze zdecydowaną przewagą pierwszego z nich, eros pojawia się stosunkowo często, zwykle

${ }^{50}$ Por. J. Naumowicz, dz. cyt., s. 32.

${ }^{51}$ Por. Methodiu, Symposion ton deka parthenon I, 4, PG 18, 44C.

52 Por. J. Naumowicz, Wstęp, s. 47-48.

${ }^{53}$ Por. Gregorius Nyssenus, Epistula 19, PG 46, 1076A.

${ }^{54}$ Grzegorz z Nyssy, De virginitate 2, PG 46, 342B; tłum. R. Cantalamessa, w: tenże, Czystego serca, Warszawa 2008, s. 95.

${ }_{55}$ Por. Gregorius Nyssenus, De virginitate 2, PG 46, 320D-321A.

${ }_{56}$ Por. A. Nygren, Agape und Eros. Gestaltwandlungen der christlichen Liebe, Berlin 1955, s. 333-342. 


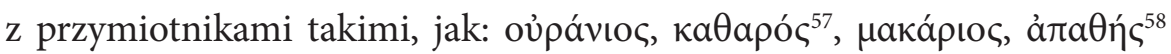
i $\theta \varepsilon \tilde{c} \varsigma^{59} \mathrm{w}$ celu oczyszczenia jego znaczenia. Kapadocczyk, mimo pełnej świadomości roli jaką termin ten odgrywał w filozofii platońskiej i tradycji greckiej, pragnie za jego pomocą wyrazić jedność człowieka $\mathrm{z}$ Bogiem, jako prawdziwy cel życia mistycznego ${ }^{60}$. W ten sposób odnosi się wrażenie zrównania treści eros $\mathrm{z}$ agape. $\mathrm{Z}$ pomocą przychodzi tu krótki urywek z napisanego w późnym okresie twórczości Grzegorza In Canticum canticorum ${ }^{61}$ : „Mówi się bowiem, że miłość jest życzliwością

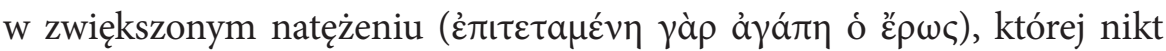
się nie wstydzi (byle tylko jej strzała nie przeszyła jego ciała), ale raczej chlubi się raną, gdy ostrze niematerialnego pragnienia wbija mu się głęboko w serce" 62 . Przytoczona definicja eros przełamuje opozycję obu pojęć, ujmując kontrowersyjny dotąd termin jako intensyfikację agape, wskazując na szczególny jej aspekt - pasyjny, intensywny i ekstatyczny. Eros jest więc rá $\theta$ os i stanowi zasadniczo aspekt bierny - pragnienia, które napotkało na nieskończony obiekt i jest przez niego nieustannie pociągany $\mathrm{w}$ taki sposób, że pozostawia człowieka jednocześnie zaspokojonym i nigdy nie nasyconym (epektaza), aż po przyjęcie radykalnej zależności od tego, co lepsze, czyli Boga ${ }^{63}$. Jest to również swego rodzaju motyw dziewiczy, pozacielesny, paralelny do opisu boskiej i czystej miłości Makryny:

Tak też okazała wszystkim ową czystą miłość do niebieskiego Oblubieńca

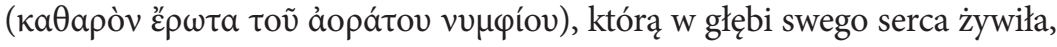
i tęsknotę za Ukochanym, by wolna od więzów ciała złączyła się z Nim jak

57 Por. Gregorius Nyssenus, De virginitate 20, PG 46, 400CD.

${ }_{58}$ Por. tenże, De instituto Christiano, GNO 8/1, s. 40.

59 Por. tenże, In Canticum canticorum, ed. H. Langerbeck, Gregorii Nysseni Opera6, Leiden 1960, s. 192.

${ }^{60}$ Por. G. Horn, Lamour divin. Note sur le mot eros chez Grégoire de Nysse, „Revue d'ascétique et de mystique" 1925, nr 6, s. 379-380; G. Maspero, dz. cyt., s. 457-458.

${ }^{61}$ Zbiór 15 homilii In Canticum canticorum powstał między 391 a 394 r. Por. P. Maraval, Chronology of works, s. 158.

${ }^{62}$ Gregorius Nyssenus, In Canticum canticorum, GNO 6, s. 383; tłum. M. Przyszychowska, w: Grzegorz z Nyssy, Homilie do Pieśni nad Pieśniami, „Źródła Myśli Teologicznej” 43, Kraków 2007, s. 199.

${ }^{63}$ Por. G. Maspero, dz. cyt., s. 461-462. 
najprędzej. I rzeczywiście biegła drogą cnoty, bo żadna życiowa rozkosz nie zdołała ku sobie pociągnąć jej oczu ${ }^{64}$.

Permanentny model doskonalenia się duchowego, jaki reprezentuje Makryna, łączy dwa ważne zagadnienia poruszane w pozostałych pismach Grzegorza: uznanie seksualności człowieka za bezpośredni owoc rajskiego grzechu, w wyniku którego doszło do drugiego stworzenia człowieka naznaczonego podziałem na płcie ${ }^{65}$ oraz epektazy - doktryny nieustannego, wiecznego pragnienia skierowanego ku Bogu, którą Kapadocczyk łączy z nienaruszoną i szczęśliwą miłością ( $\mathrm{w}$ jednym $\mathrm{z}$ napisanych $\mathrm{w}$ ostatnich latach życia pism - De instituto Christiano $^{66}$ :

Jeśli ktoś nieznacznie oderwie swą myśl od ciała, a także uwolni się od więzów namiętności i bezmyślnych działań, po czym szczerze, czystym sercem spojrzy na własną duszę, w jej naturze wyraźnie dostrzeże miłość (ảyárnv) Boga ku nam oraz wolę Stwórcy. Dzięki takiemu spojrzeniu odkryje, że do istoty i natury człowieka należy pragnienie tego, co piękne i dobre; i że z naturą tą ściśle wiąże się niewzruszona i szczęśliwa miłość

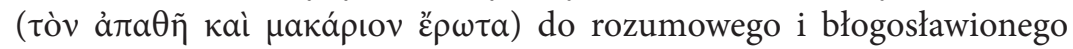
Obrazu, którego człowiek stanowi odwzorowanie ${ }^{67}$.

Acielesność pragnienia zostaje równie mocno podkreślona $\mathrm{w}$ In Canticum canticorum, gdzie Grzegorz stwierdza: „miłość Boga ( Tòv $\theta \varepsilon i ̃ o v$ $\varepsilon \Leftarrow \rho \omega \tau \alpha)$ rodzi się $\mathrm{z}$ tego, co jest przeciwne cielesnemu pragnieniu, więc jeśli tamto poprzedza osłabienie, rozluźnienie i leniwe rozmiękczenie, tutaj

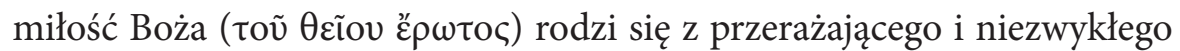
męstwa" ${ }^{68}$. Stąd również w biografii Świętej nie brakuje motywu rezygnacji

${ }^{64}$ Gregorius Nyssenus, Vita sanctae Macrinae, PG 46, 984A; tłum. W. Kania, w: Grzegorz z Nyssy, Życie św. Makryny, „Analecta Cracoviensia” 1971, nr 3, s. 397.

${ }^{65}$ Por. Gregorius Nyssenus, De opificio hominis 16, ed. J. P. Migne, Patrologiae cursus completus. Series Graeca 46, Paris 1863, 180D-184A.

${ }^{66}$ Por. P. Maraval, Chronology of works, s. 159.

${ }^{67}$ Gregorius Nyssenus, De instituto Christiano, GNO8/1, Leiden 1963, s. 40; tłum. J. Naumowicz, w: Grzegorz z Nyssy, O celu życia i prawdziwej ascezie, w: tenże, O naśladowaniu Boga. Pisma ascetyczne, BOK 15, Kraków 2001, s. 99. Zob. także: G. Nyssenus, De anima et resurrectione, PG 46, 93C.

${ }^{68}$ Gregorius Nyssenus, In Canticum canticorum, GNO 6, s.192; tłum. M. Przy- 
z ludzkiej miłości, bowiem Makryna postanowiła pozostać wierna jednemu mężczyźnie, mimo iż umiera on jeszcze w okresie narzeczeństwa ${ }^{69}$. Znamienny jest fakt, że w opisie tej miłości Nysseńczyk nie używa czasownika erao, lecz stergein, określający relacje wewnątrzrodzinne, jeszcze dobitniej podkreślając czystość serca siostry, pragnącej jedynie samego Boga $^{70}$. Tym samym Makryna realizuje podstawowy postulat ideału dziewiczego życia: „jedynie miłość ( $\tau$ òv ع̋ $\rho \omega \tau \alpha)$ jest bożym życiem”71, a jej natura ludzka „oparta na skłonności do ulegania żądzom w ofierze czystości wzrasta $\mathrm{w}$ górę, jak gdyby [była] podnoszona $\mathrm{z}$ upadku przez wyciągniętą dłoń i skłaniana, by spoglądała w niebo"72. I choć powyższe stwierdzenia stanowią koherentne cytaty z De virginitate, Grzegorz bezpośrednio wyraża je w relacji agonii Makryny: „jej żarliwość jednak nie ustawała, lecz im bardziej zbliżał się koniec, tym ona więcej zdawała się wpatrywać w piękność Oblubieńca i z tym żywszym pragnieniem tęskniła za Umiłowanym, słabnącą mowę kierując już nie do nas, przy niej obecnych, ale do Tego, w którym wzrok swój utkwiła." ${ }^{73}$

\section{c. $\varphi ı \lambda о \sigma o \varphi i ́ a$}

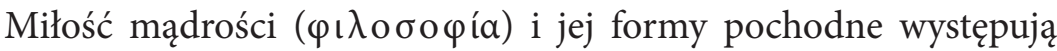
w samym Vita sanctae Macrinae aż 16 razy $^{74}$, dlatego też termin ten stanowi niejako klucz do kompletnego odczytania istoty miłości, której wzór Grzegorz kreśli w osobie Makryny, a także ich matki Emmalii:

szychowska, w: Grzegorz z Nyssy, Homilie do Pieśni nad Pieśniami, „Źródła Myśli Teologicznej” 43, Kraków 2007, s. 107-108.

69 Por. Gregorius Nyssenus, Vita sanctae Macrinae, PG 46, 962CD. Przez śmierć narzeczonego, któremu Makryna postanowiła pozostać wierną, gdyż „żyje on w Bogu”, łączy w sobie dwa wzajemnie wykluczające się pojęcia kobiety: niezamężną i wdowę. Metoda łączenia w kreowaniu wizerunku Makryny przeciwieństw na celu podkreślić wyjątkowość siostry. Por. J. Dybała, Ideał kobiety, s. 295.

${ }^{70}$ Por. Gregorius Nyssenus, De virginitate 5, PG 46, 348C-349A; tłum. R. Cantalamessa, w: tenże, Czystego serca, Warszawa 2008, s. 40-41.

${ }^{71}$ Gregorius Nyssenus, De virginitate 4, PG 46, 340D.

72 Tamże, PG 46, 321D-324A; tłum. własne.

73 Tamże, Vita sanctae Macrinae, PG 46, 984B; tłum. W. Kania, w: Grzegorz z Nyssy, Życie św. Makryny, „Analecta Cracoviensia” 1971, nr 3, s. 397.

74 Por. L. Karfíková, Gregory of Nyssa, s. 18-19. 
[...] ich natura wolna była od ludzkiej namiętności, to już przechodziło siłę ludzką, że zaś były w ludzkim ciele i używały zmysłów, w tym stały niżej od natury aniołów i bezcielesnych istot. Może nawet kto powie, iż ta różnica nie oznacza wielkiej odległości. Bo skoro w ciele żyły na sposób bezcielesnych Potęg, nie obciążało ich ciało, lecz wzniosły się ku górze, ku niebu, gdzie się właśnie przebywa z niebieskimi Potęgami. I czas takiego życia nie trwał wcale krótko, a wraz z nim powiększał się i zysk, gdyż umiłowanie ascezy ( $\tau \tilde{\eta} \varsigma \varphi \iota \lambda о \sigma o \varphi$ ía) przez nowo uzyskane dobra rodziło dalsze postępy w kierunku jeszcze większej czystości ${ }^{75}$.

W powyższym cytacie, podobnie jak w pozostałych fragmentach dzieł poświęconych Makrynie, w których pojawia się termin filozofia, staje się on synonimem klasztornego lub quasi-monastycznego życia poświęconego pracy i ubóstwu ${ }^{76}$, czyli podstawowych form ascezy, które $\mathrm{w}$ rezultacie prowadzą do pomnożenia stanu apathei i czystości duszy. Dlatego tak ważnym modelem w kreacji postaci Świętej jest odwołanie się do istoty bytów anielskich, z którymi Makryna zostaje zrównana, $\mathrm{z}$ jedną tylko różnicą - pozostawania w ciele ${ }^{77}$. Metafora dziewic jako bytów anielskich ma swój początek w tekstach ewangelicznych, zaś do literatury antycznej trafiła $\mathrm{w}$ okresie rozpropagowywania renuncjacyjnych wysiłków chrześcijan, czyli na przełomie III i IV w. ${ }^{78}$ Co więcej, tak ujęty problem dziewictwa prowadzi do otwarcia człowieka na czystą i boską

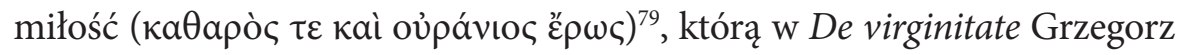
zrównuje z posiadaniem miłości do prawdziwej mądrości:

Chrystus jest wszystkim dla wszystkich istot ludzkich, prawdziwym

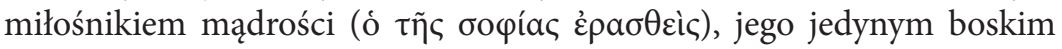
celem jest prawdziwa mądrość, a dusza, przywiązana do nieskazitelnego Oblubieńca, posiada miłość do prawdziwej mądrości, którą jest Bóg ${ }^{80}$.

${ }^{75}$ Gregorius Nyssenus, Vita sanctae Macrinae, PG 46, 972AB; tłum. W. Kania, w: Grzegorz z Nyssy, Życie św. Makryny, „Analecta Cracoviensia” 1971, nr 3, s. 392.

${ }^{76}$ Por. L. Karfíková, Gregory of Nyssa, s. 20.

77 Por. Gregorius Nyssenus, Epistula 19, PG 46, 1076A.

${ }^{78}$ Por. J. Dybała, Ideał kobiety, s. 83.

79 Por. Gregorius Nyssenus, De virginitate 20, PG 46, 400CD.

${ }^{80}$ Tamże; tłum. własne. 
W niebanalny sposób Nysseńczyk wprowadza kategorię eros wobec

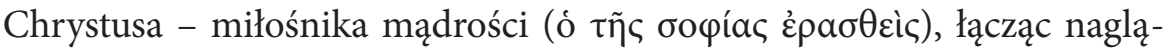
ce pragnienie tego, co się podoba z miłością ascezy i kontemplacji jako dwóch skrzydeł starożytnego pojęcia filozofii. Tym samym Grzegorz znajduje prawdziwe znaczenie „filozofii boskiego wznoszenia”, którą, zdaniem A. Nygrena, jeszcze klarowniej Nysseńczyk prezentuje w In Canticum canticorum w platońskim obrazie strzały - duszy, która przez Chrystusa zostaje wprowadzona do cięciwy łuku i wystrzelona do niebiańskiego celu. Nygren podkreśla jednak, że siłą, która powoduje owe wzniesienie duszy, jest pragnienie miłości, co z kolei wskazuje, że między agape a niebiańskim eros zachodzi równość ${ }^{81}$.

Zestawienie filozofii z erosem stanowi nowe ujęcie miłości w świecie wczesnochrześcijańskim, wywyższające miłość nad wiedzę ${ }^{82}$. Prawdę tę Grzegorz wkłada w usta Makryny w Dialogus de anima et resurrectione: „Gdy już mamy to, czego się spodziewaliśmy, ze wszystkich uczuć pozostaje tylko czynna siła miłości ( nic nie może zająć jej miejsca. Ona dzierży pierwsze miejsce tak wśród ćwiczeń cnoty, jak i wśród przepisów prawa" ${ }^{33}$. W Dialogu obraz filozofii, która wzniosła Makrynę na najwyższy szczyt ludzkiej mocy, zyskuje więc bardziej spekulatywny charakter, zamykając ją ostatecznie nie tylko w obrębie klasztornej ascezy, lecz także w duchowej medytacji, „umiłowania mądrości” w pełni greckiego znaczenia, jako moralnego i intelektualnego wysiłku $^{84}$, a samą Świętą stawia w roli ideału chrześcijańskiego filozofa życia ${ }^{85}$. Warto przy tym zauważyć, że przy okazji tak skonstruowanej definicji filozofii powraca temat dziewictwa, które - w myśl De virginitate realizuje się dzięki sile miłowania zwróconej ku kontemplacji piękna duchowego ${ }^{86}$.

${ }^{81}$ Por. A. Nygren, Agape und Eros, s. 346.

${ }^{82}$ Por. G. Maspero, dz. cyt., s. 460.

${ }^{83}$ Gregorius Nyssenus, De anima et resurrectione, PG 46, 96B; tłum. W. Kania, w: Grzegorz z Nyssy, Wybór pism, Warszawa 1974, s. 61.

${ }^{84}$ Por. L. Karfíková, Gregory of Nyssa, s. 22.

${ }^{85}$ Por. S. Leuenberger-Wenger, Ethik und christliche Identität bei Gregor von Nyssa, Tübingen 2008, s. 347; J. Dybała, Ideał kobiety, s. 315.

${ }^{86}$ Por. Gregorius Nyssenus, De virginitate 5, PG 46, 348D. 
Warto także podkreślić, że ideał filozofa, dzięki któremu Święta upodobniła swój stan do aniołów, dzięki przezwyciężeniu natury ludzkiej, a nie tyle cech właściwych kobiecie ${ }^{87}$, stawia ją w sytuacji paralelnej do ideału św. Pawła Apostoła. Zdaniem Nysseńczyka Makryna poprzez praktykowanie ascezy, apathei i wolności urzeczywistnia męską naturę oraz przeznaczenie ${ }^{88}$, osiągając pełnię szczęścia, dlatego zostaje przedstawiona w roli mentorki, która własnym życiem przeszła drogę wzniesienia się ku boskim rzeczywistościom. Stąd w Dialogach za jej pośrednictwem Grzegorz wykłada kluczowe dla duchowego życia chrześcijan pouczenia, które oscylują wokół zagadnienia realizacji w naturze ludzkiej udzielonego jej w akcie stwórczym i osłabionego przez grzech pokrewieństwa z Bogiem:

Kiedy dusza wzniosła się na ten szczyt, nie potrzebuje już innego dobra, gdyż obejmuje pełnie wszelkiego bytu. Wydaje się, że sama może w sobie w jakiś sposób zmieścić to, co stanowi Boże szczęście. Bo i życie najwyż-

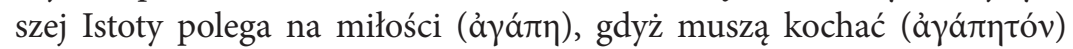
dobro ci, którzy je znają. Bóg poznaje siebie; to zaś poznanie staje się

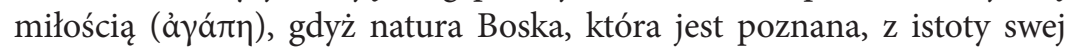
jest dobra. $Z$ prawdziwym dobrem nie łączy się żaden przesyt. Skoro więc żadne uczucie sytości nie przeszkadza odniesieniu miłości ( $\tau \grave{\eta} v$

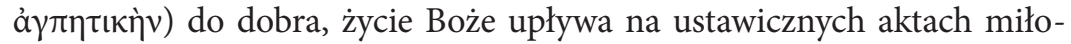

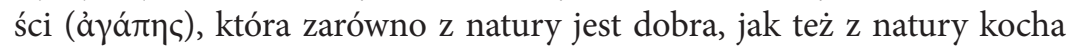

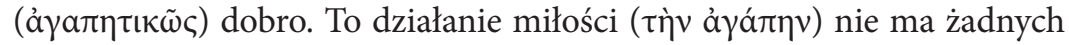
granic, bo i dobru nie da się wytyczyć granicy. Dlatego dopiero na granicy dobra kończy się i miłość ( wieństwie ustaje dobro. Ten zaś, którego natura niezdolna jest do złego, musi posiadać bez końca i bez granic dobro. Każda natura przyciąga do siebie to, co jest pokrewne. A ponieważ człowiek wzniósł się do pokrewieństwa z Bogiem przez swe podobieństwo do wzoru, musi duszę pociągać pokrewna jej boskość. To zaś, co należy do Boga, musi być zbawione ${ }^{89}$.

${ }^{87}$ Por. R. Wiśniewski, Makryna, s. 309-311.

${ }^{88}$ Por. S. Leuenberger-Wenger, Ethik und christliche Identität, s. 345-346.

${ }^{89}$ Gregorius Nyssenus, De anima et resurrectione, PG 46, 96C-97A; tłum. W. Kania, w: Grzegorz z Nyssy, Wybór pism, Warszawa 1974, s. 61. 


\section{PODSUMOWANIE}

Choć bezpośrednie przywołanie postaci Makryny w całym dorobku Grzegorza z Nyssy pojawia się zaledwie w trzech pismach - Vita sanctae Macrinae, Dialogus de anima et resurrectione oraz Epistula 19, jednak przy bliższej lekturze spuścizny Kapadocczyka z łatwością można poszerzyć ich katalog o paralelny tematycznie, choć spisany znacznie wcześniej, jeszcze przed śmiercią Świętej, traktat ascetyczny De virginitate. Cechą łączącą wspomniane dzieła jest niewątpliwie ukazanie ideału życia chrześcijańskiego, pojętego jako odwzorowanie Boskiej natury przez postęp na

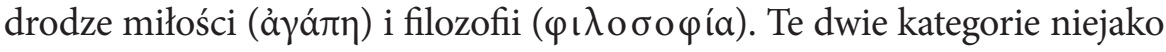
uzupełniają się wzajemnie, prowadząc do ukształtowania w człowieku go-

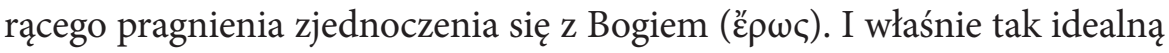
koncepcję synergizmu różnych oblicz miłości w życiu chrześcijańskim urzeczywistnia w oczach Nysseńczyka jego wielka siostra Makryna, stając się paradygmatem wzniesienia natury ludzkiej ku cechom właściwym rzeczywistości anielskiej - czystości duszy i ciała, apathei oraz wolności.

Kreślona przez Grzegorza „filozofia boskiego wznoszenia”, a więc droga życia Makryny, dokładniej wyjaśniona za pomocą oblubieńczej relacji In Canticum canticorum, prowadzi do uznania zasadniczej prawdy progresu duchowego - Chrystus zapoczątkowuje rosnące w duszy pragnienie miłowania, które podnosi naturę ludzką drogą ascezy i kontemplacji ku niebu. Z drugiej strony postać Makryny wskazuje, że pełna realizacja

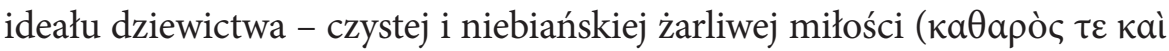

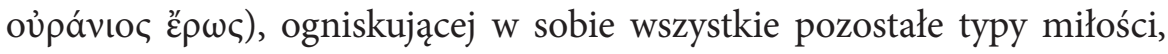
dzięki czemu staje się zwielokrotnieniem ảyár tologii w doczesność. Dziewictwo staje się znakiem stanu sprzed upadku, pierwotną drogą natury ludzkiej, dlatego też w pismach Nysseńczyka zostaje przedstawione jako rzeczywistość boska, która z racji doczesnego związania z cielesnością, musi pozostawać w jej granicach. W ten sposób Żywot Makryny staje się antycypacją wiecznej doskonałości tych, którzy podążają drogą miłości, by osiągnąć upragnione zjednoczenie z Miłością-Agape, z łona której zrodziła się cała ludzkość. 
Streszczenie. Ideał życia chrześcijańskiego. Sylwetka św. Makryny Młodszej w pismach św. Grzegorza z Nyssy. Postać św. Makryny, przywoływanej we wspomnieniach św. Grzegorza z Nyssy w Epistula 19, Vitae sanctae Macrinae oraz Dialogus de anima et resurrectione, stanowi swoiste wcielenie ideału miłości chrześcijańskiej. Życiowa droga Świętej, która od najmłodszych żarliwie pragnęła zjednoczenia z Bogiem, wiedzie

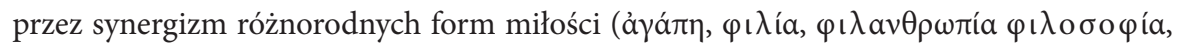

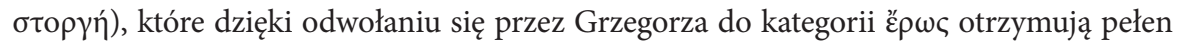
pasji i ekstatyczności wyraz. Makryna obrazuje więc paradygmat filozofa miłości, który, dzięki własnemu doświadczeniu, poucza o wyżynach zażyłości z Bogiem, sama zaś za pomocą modlitwy, kontemplacji i pracy na rzecz bliźnich osiąga szczyty wzniesienia się

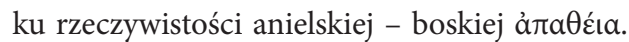

Słowa kluczowe: Makryna; miłość; dziewictwo; agape; eros; filozofia.

Abstract. The Ideal of Christian life. The Figure of st. Macrina the Younger in the writings of St. Gregory of Nyssa. St. Macrina, mentioned in St. Gregory's of Nyssa memories included in Epistula 19, Vitae sanctae Macrinae and Dialogus de anima et resurrectione, shows specific embodiment of ideal of Christian love. Way of life of St. Macrina, who wanted to be unified with God from an early age, leads through synergism

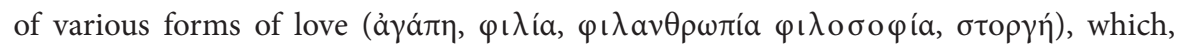
owing to St. Gregory's references to category of $\varepsilon \rho \omega \varsigma$, gainful of passion and ecstatic expression. Therefore Macrina represents a paradigm of philosopher of love, who, thanks to her own experience, teaches about heights of intimacy with God and supported by prayer, contemplation and work for neighbor, reaches top levels of voyage to angelic and

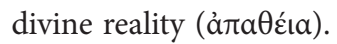

Keywords: Macrina; love; virginity; agape; eros; philosophy. 